\title{
A Clay Gladius Scabbard from Area 13c in the Ancient Roman Town of Syene
}

\author{
MARIOLA HePA
}

\begin{abstract}
Area 13c, located in the town centre of modern Aswan in Upper Egypt, was excavated in 2005 by the Joint Swiss-Egyptian Mission working at Old Aswan. A sequence of houses from the late Ptolemaic period up to the late Roman period was documented at the site. Among the terracotta objects found in one of the houses, a miniaturised clay scabbard has features typical for the gladius scabbards known from military camps of the first and early second centuries AD from other Roman provinces. Similar terracottas were interpreted as toys, attributes of statues or votive offerings. However, the find context of the object from Syene demonstrates that - together with other clay objects - it belonged to a room decoration or was part of a house altar. Perhaps the object was dedicated as a votive by a soldier, since there are some indications for Roman military presence in this part of Syene.
\end{abstract}

Keywords: Roman Egypt, Syene, Area 13c, terracotta, gladius, votive object

Mariola Hepa, Swiss Institute for Architectural and Archaeological Research on Ancient Egypt in Cairo, Cairo; mariolahepa@googlemail.com

Syene, the ancient town of Aswan, is located at the first cataract of the Nile and was the southernmost city of the Roman Empire. It was one of the most important cities of Upper Egypt from the Graeco-Roman to the Islamic period. ${ }^{1}$

In October 2000 the Swiss Institute for Architectural and Archaeological Research on Ancient Egypt in Cairo together with the Ministry of State for Antiquities at Aswan began an extensive and long-term urban archaeological project at Old Aswan. ${ }^{2}$ The objective of

\footnotetext{
1 Locher 1999: 60-61; Martin-Kilcher, Wininger 2017: 2.

2 The project is directed by Cornelius von Pilgrim (Director of the Swiss Institute for Architectural and Archaeological Research on Ancient Egypt, Cairo) in close cooperation with Abd El-Moneim Said Mahmoud (Director of the Supreme Council of Antiquities, Aswan) and the field director Wolfgang Müller (Swiss Institute for Architectural and Archaeological Research on Ancient Egypt in Cairo); Pilgrim 2011: 79-84.
} 


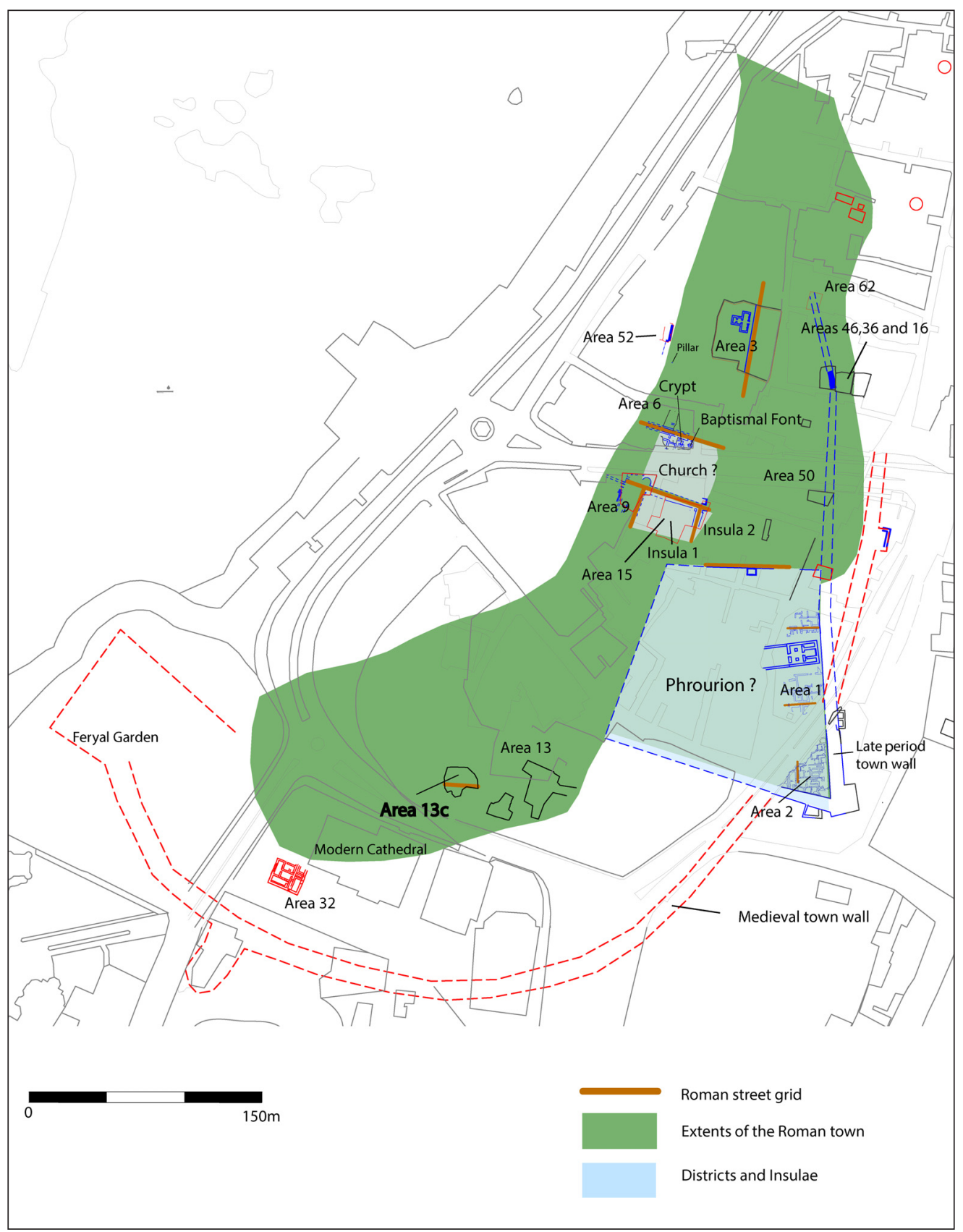

1. Location of Area 13c in the Graeco-Roman city of Syene (Müller 2014: Pl. 2). 

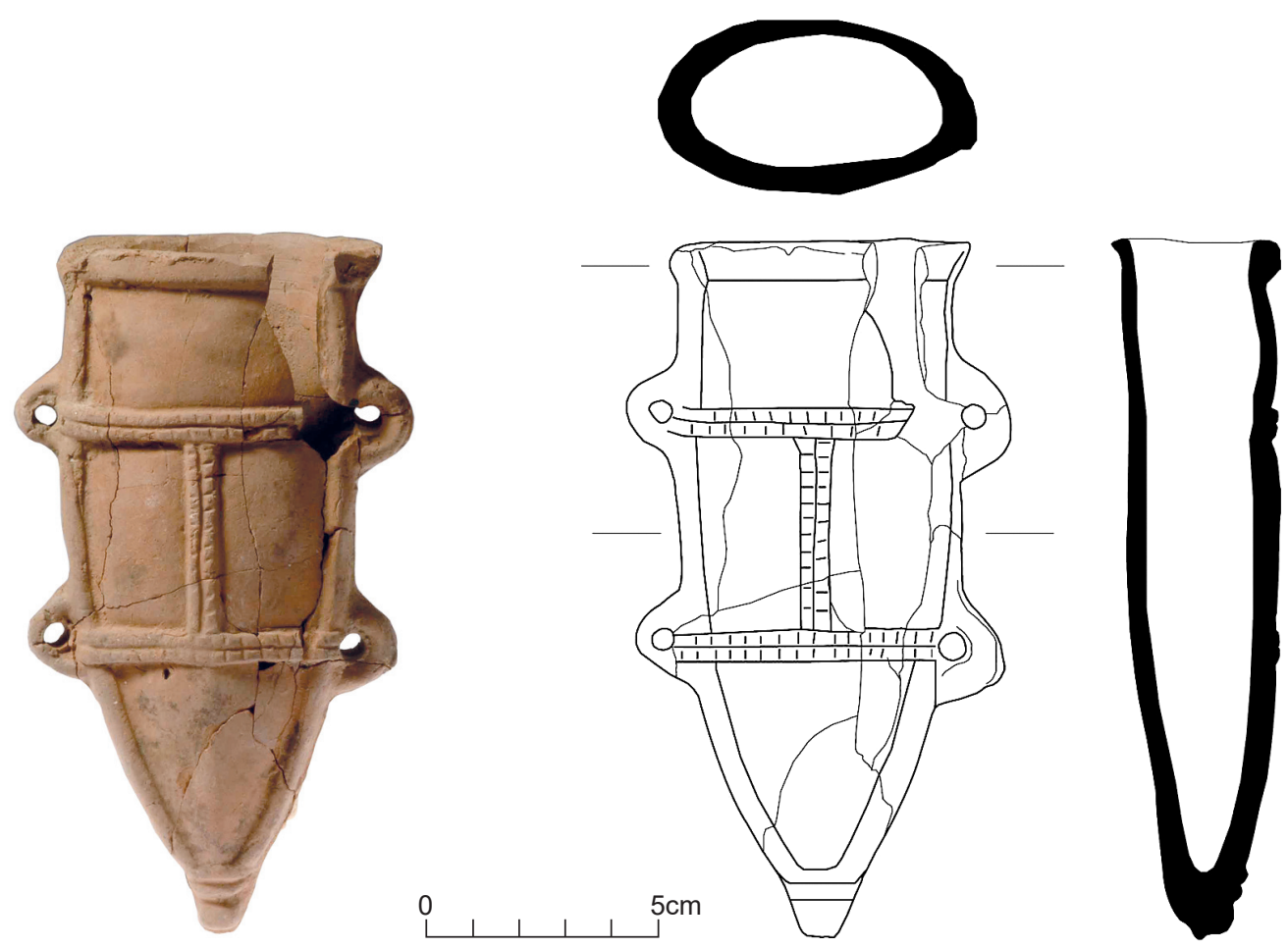

2. A decorated sword scabbard from Area 13c in Syene (Phot. A. Krause; drawing: O. von Pilgrim (C) Swiss Institute).

this project is to research the history of the town of Aswan from its beginnings to the early Modern Age by means of systematic rescue excavations. ${ }^{3}$

The rescue excavations were conducted in Area 13c (Fig. 1), ${ }^{4}$ located to the north of the modern Archangel Michael's Coptic Orthodox Cathedral and to the south of the Abu El-Eila mosque. Here, remains of several buildings were unearthed, which dated from the third century $\mathrm{BC}$ to the third century $\mathrm{AD} .{ }^{5}$ These indicate a continuous and dense occupation in this district. In addition to the numerous finds of pottery, ${ }^{6}$ glass and some small metal objects, a large number of fragments from terracotta objects were found there. ${ }^{7}$ One of them was a completely preserved decorated scabbard made of local Aswan clay (Fig. 2). ${ }^{8}$

\footnotetext{
3 Pilgrim et al. 2004: 119.

${ }_{4}$ The excavations at the site were conducted in fifth and sixth season (2005-2006) under the direction of Cornelius von Pilgrim and Patrick Moser.

5 Pilgrim et al. 2006: 215; Hepa 2012: 13.

${ }^{6}$ The pottery was studied by Laura Rembart, Austrian Archaeological Institute, Vienna; see: Rembart 2018.

7 The terracottas are studied by Martin Fink, Cultural Office Kempten, as a part of the PhD thesis.

8 The object with the inventory number 5-13-244-4/1 is stored in the magazine of SCA in Aswan.
} 


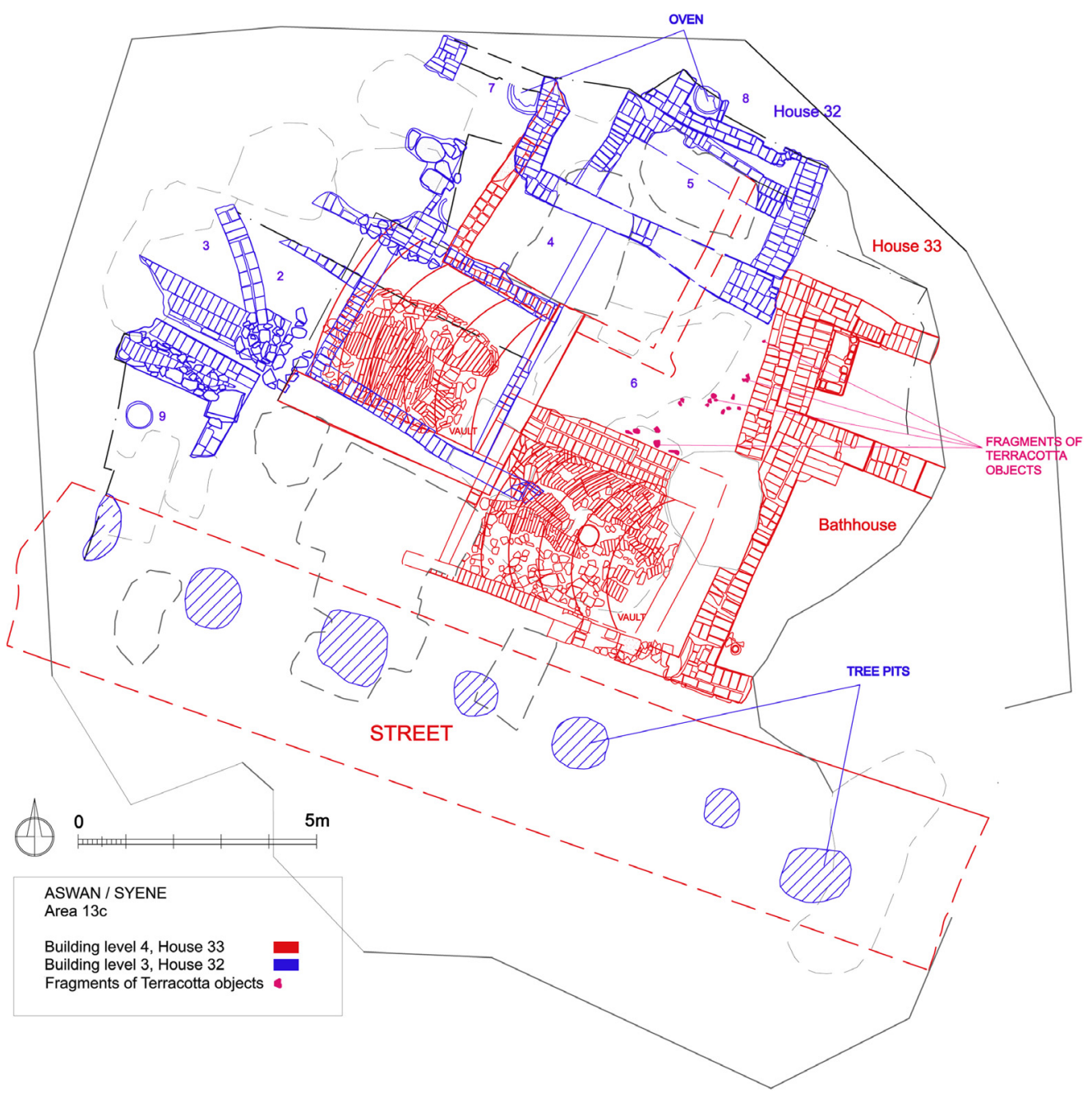

3. Plan of Area 13c with find spot of the terracotta objects (Drawing: M. Hepa (C Swiss Institute).

The object was found on top of the mud-floor of Room 6 in House 32, attributed to Level 3 (Fig. 3). The house was stratigraphically situated above House 33 (Level 4), dismantled systematically prior to the construction of House $32 .{ }^{9}$ House 32 had nine rooms, which were repeatedly rebuilt. Some rooms of the older House 33 were reused in the structure of House 32. These include vaulted Rooms 1 and $5,{ }^{10}$ as well as two bathrooms in the eastern area of the building (Fig. 3) ${ }^{11}$ Due to its poor state of preservation, the function of

\footnotetext{
9 Hepa 2012: 22-23.

10 Hepa 2014: 155, Fig. 2.

11 Müller, Hepa 2017: 55-57.
} 


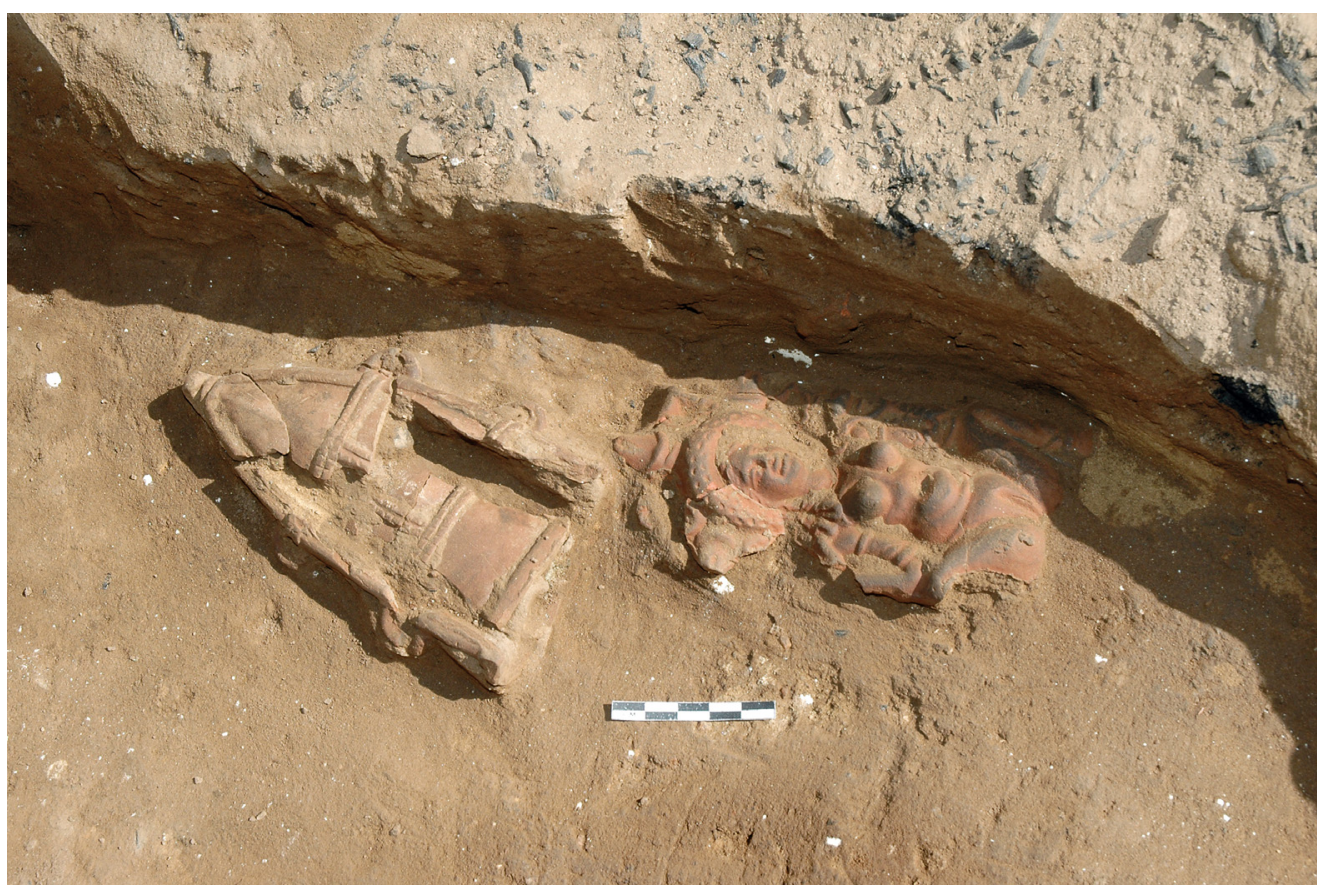

4. Sword scabbard as found together with other terracotta objects (Phot. P. Moser (C) Swiss Institute).

House 32 is unclear, but the older buildings in the same place have a domestic character. The only installations found in House 32 were bread ovens in Rooms 7 and 8, and a vessel (probably used for storage) set into the floor of Room 9, both hinting at a domestic use of the house.

South of the building was an east-west oriented street, which was already in use during Level 4. Circular pits on the side of the street indicate that it was flanked by trees like an avenue. ${ }^{12}$ The rest of the house was severely destroyed by later constructions and modern robbery pits.

Level 4 was dated by the pottery and the numismatic evidence from the first century $\mathrm{BC}$ to the beginning of the second century $\mathrm{AD}$, thus providing a terminus ante quem for the construction of House $32 . .^{13}$

The scabbard was found in situ near the eastern wall of the room together with other terracottas including a fragmented statuette, probably of a rooster, part of a basket and a figurine of a Baubo (Fig. 4) ${ }^{14}$ Furthermore, there were at least fourteen other fragments of terracotta figurines in Room 6, lying alongside its east and south walls (Fig. 3). Besides the ceramic material, three badly corroded Aes coins and a piece of charred basketry were

\footnotetext{
${ }^{12}$ Hepa 2012: 24.

${ }^{13}$ The coins are studied by Hans-Christoph Noeske, Academy of Science and the Literature, Mainz. For the dating based on pottery, see: Rembart 2018: 415-417.

${ }^{14}$ These terracottas are analysed by Martin Fink; see above, note 7.
} 
found in the room..$^{15}$ The layer directly on top of the walking level with the terracottas, also contained a significant amount of terracotta fragments and some coins. ${ }^{16}$

The terracotta scabbard has a height of $15 \mathrm{~cm}$ and a maximum width of $7 \mathrm{~cm}$. The object is hollow and the opening has a length of $7 \mathrm{~cm}$ and a width of $3 \mathrm{~cm}$. With a depth of $12.5 \mathrm{~cm}$ the interior of the scabbard offers space for another object made of terracotta, wood or other material (Fig. 2).

The front side of the terracotta is decorated with a relief and a centrally positioned pair of rings on each long side of the scabbard. The rings bear traces of wear, perhaps of a cord or another sort of string. In addition, two horizontal strips extend between each of the opposite rings. Another vertical strip, connecting the two horizontal ones in the middle of the scabbard surface creates a grid-like pattern on the front of the object. Each strip is composed of two parallel strips, covered by transverse incisions. The horizontal strips seem to imitate a suspension system. A frame along the long sides of the scabbard, terminates in a ribbed knob. The backside of the object is smooth.

The form of the object shows similarities to a Roman dagger (pugio) scabbard, which is particularly visible in the slightly inwardly-curved form that is typical of daggers found in, for instance, the Vesuvius region in Italy, ${ }^{17}$ the Celtic oppidum at Titelberg in Germany ${ }^{18}$ and the Roman town of Exeter (Isca Dumnoniorum) in Britain. ${ }^{19}$ The squat form of the object with only two horizontal strips is also similar to a Roman dagger, as is attested by an example from Speyer (Noviomagus) in Germany. ${ }^{20}$

However, there are several aspects of the decoration, which suggest that this terracotta represents the scabbard for a Roman sword (gladius). As described above, the scabbard has a V-shaped frame along the long sides of the object terminating in a ribbed knob. This corresponds to the scabbard of a gladius ('Rahmenscheide' Miks type Pompeii), which also has $\mathrm{V}$-shaped frame ending in a ribbed $\mathrm{knob}^{21}$ and dates to the early Imperial period. Many of the scabbards of this type were adorned with thin sheets of bronze decorated with palmettes or figural scenes, but in our case, the scabbard is kept unadorned..$^{22}$

The strips that run across the terracotta scabbard from Area 13c are typical of pugio scabbards dating to the Roman Republic. ${ }^{23}$ A close parallel to our example - especially

${ }^{15}$ The coins inventory numbers 5-13-244-4/15, 4/16, 4/17 and the basket fragment 5-13-244-4/10 are stored in the magazine of SCA in Aswan.

16 The coins inventory numbers 5-13-244-1/3, 1/8, 1/12 come from the filling of the house; these are badly corroded Aes, which are generally dated from third to second century BC.

17 Ortisi 2015: 23, Pl. 80, cat. no. A23.

${ }_{18}$ Saliola, Casprini 2012: 123, Fig. 216.

${ }^{19}$ Saliola, Casprini 2012: 127, Fig. F35.

${ }^{20}$ Saliola, Casprini 2012: 121, Fig. 208.

${ }^{21}$ Miks 2007: Vortafel E, no. 48; Ulbert 1969: Pl. 32/2.

${ }^{22}$ Ulbert 1969: 120; for the pictorial decoration with palmettes on Pompeii gladii, cf. detailed description in Ulbert 1969: 111-115 and Ortisi 2015: 20, Pl. 2, cat. no. A5; Pl. 3, cat. no. A7-8.

${ }_{23}$ Obmann 2000: Pls 27/3, 28/1, 29/1. 
in the depiction of the strips and the knob - is shown on the relief of the tombstone of Minucius from Padua (Patavium) from the first century $\mathrm{BC}^{24}$ but here, the suspension rings on both sides are not pictured. Minucius' dagger seems to be suspended on only two rings positioned just under the mouth of the scabbard. ${ }^{25}$ Another component shown on the tombstone is the frame, ${ }^{26}$ which is connected to the suspension-rings, and is also missing on the example from Area 13c.

The simple, stocky and ribbed knob is similar to gladii of the Pompeii type as presented by Günter Ulbert. ${ }^{27}$ This whole decoration is mainly found on the scabbards of the Pompeii type, as examples from Windisch (Vindonissa), ${ }^{28}$ Xanten (Castra Vetera; Castra Ulpia Traiana $)^{29}$ and Augst (Augusta Raurica) demonstrate. ${ }^{30}$

The horizontal strips represent components of a suspension system that, according to Christian Miks is characteristic for the early Imperial period and corresponds to his type $27 .{ }^{31}$ Examples with this type of suspension were found in the legionary camp of Colchester

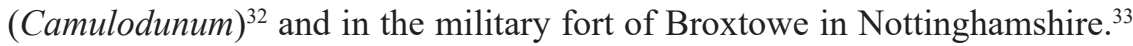

Another dating element is the vertical strip connected to the suspension components and creating a grid-like pattern. This detail is also found on scabbards with net-like fittings that are fixed both on the tip and on the scabbard as a whole. ${ }^{34}$ These scabbard elements were dated by Miks into the early Imperial period. ${ }^{35}$ Other examples for this decoration can be found on the Magdalensberg (Noreia?) ${ }^{36}$ and in Saintes (Mediolanum Santonum). ${ }^{37}$ A scabbard from the River Ljubljanica is covered with a net-like fitment in toto. ${ }^{38}$ On the scabbards from Magdalensberg and Ljubljanica, both suspension components pass through pairs of upper and lower rings, ${ }^{39}$ as is the case with the terracotta scabbard from Area 13c. It cannot be excluded that the grid-like decoration imitates leather or textile strips, which are running through the suspension rings in order to fix the scabbard on the belt (cingulum). ${ }^{40}$ The central position of the suspension rings and the strips is more often found on sword scabbards than on those belonging to daggers, where the upper band of the scabbard is

\footnotetext{
${ }^{24}$ Obmann 2000: P1. 59/1-2; Bishop, Coulston 2006: 57.

25 Obmann 2000: 5.

26 Fischer 2012: 193, Fig. 274.

27 Ulbert 1969: 120.

28 Unz, Deschler-Erb 1997: 16, P1. 9, no. 167; Miks 2007: P1. 212/B328, 178.

29 Schalles, Schreiter, Boelicke 1993: 201, Fig. 32, P1. 33; Miks 2007: P1. 212/B13, 45.

${ }^{30}$ Deschler-Erb 1999: 137, Pl. 10/136; Miks 2007: P1. 212/B335.

31 Miks 2007: Vortafel E, no. 47.

32 Crummy, Moyes, Bayley 1992: 237, Fig. 6.36/374; Miks 2007: Pl. 195/B67, 5.

33 Webster 1958: 70, Fig. 3/7; Miks 2007: P1. 195/B45, 1.

34 Istenič 2003: 271-274.

35 Miks 2007: Vortafel E, no. 38.

36 Dolenz 1998: 309, P1. 1/M1; Miks 2007: P1. 200/A459.

37 Feugère 2002: 12, Fig. 1; Miks 2007: P1. 200/B252, 1.

38 Istenič 2003: 276, Fig. 7b.

39 Miks 2007: P1. 200/A459.

40 Ulbert 1969: 117; Miks 2007: Vortafel E, no. 45; Fischer 2012: 195.
} 
usually fixed directly under the mouth in connection with the lower suspension rings as both archaeological finds ${ }^{41}$ and representations on stone show. ${ }^{42}$

Although the squat form of the scabbard from Aswan is reminiscent of a dagger, the curved shape is also found in short swords. According to Miks, the Pompeii type has two variants that have a similarly curved shape, namely Putensen-Vimose and Hamfelde. ${ }^{43}$

To sum up, the early Imperial examples of scabbards of gladii show a marked similarity of the decorative elements to those visible on the terracotta scabbard. It therefore seems likely that the terracotta is a miniaturised and slightly compressed imitation in terracotta of the scabbards for a Pompeii type gladius (of the Putensen-Vimose or Hamfelde variants), mixed with characteristics from gladii of the Mainz type, dating from the first century $\mathrm{BC}$ to the first century $\mathrm{AD} .{ }^{44}$ On the other hand, an almost identical construction is also known from dagger scabbards found in the Vesuvius region. ${ }^{45}$

There is abundant literature on both the Roman gladii and pugiones and on terracotta models of swords and scabbards, with the latter originating predominantly from Egypt. Most examples of terracotta scabbards and swords come from collections and are of an unknown provenance. Their dating is therefore questionable. A complete dagger and its scabbard from Egypt, acquired in Cairo and now in the Academic Art Museum of the University of Bonn (Germany), is dated to the early Roman Imperial period based on the characteristics of the scabbard such as the lateral suspensions. ${ }^{46}$ Another similar object, having still a sword or dagger made of clay inside, was found in Naukratis, and was associated with a terracotta workshop dated to the early Roman Imperial period. ${ }^{47}$ The object is dated by Donald Bailey from the third to first century BC. ${ }^{48}$ Two other objects, with both dagger/sword and scabbard preserved, are kept in the Museum in Alexandria, and were also acquired from dealers. ${ }^{49} \mathrm{~A}$ fragmentary sword knob of unknown origin is now in the collection of classical antiquities in the Fine Arts Museum in Budapest and was dated on the basis of analogies to the late Hellenistic or early Roman Imperial period. ${ }^{50}$ Another fragment of a terracotta sword or dagger, now in the Ny Carlsberg Glyptotek in Copenhagen, was dated roughly to the Roman Imperial period. ${ }^{51}$

${ }^{41}$ Obmann 2000: 5, Pls 1/GB 2, 4/GB 22, 6/NL 4, 11/D 21, 14/D 23, 16/D 30, F 2, 17/D 33, 18/CH 5, 20/CH 13, 21/I 1, 23/HR 2, 24/HR 3, 1, 26/1, 27/3, 29/1 (these are only scabbards with preserved suspension rings; there are also several scabbards without suspension rings: Pls 2/GB 14-15, 3/GB 18, 4/GB 22, 7/NL 8); Saliola, Casprini 2012: 119, Figs 191-192; 120, Figs 197, 200-201; 121, Figs 206-208; 122, Figs 209-211; 123, Figs 215-216; 125, Fig. F8; 126, Fig. F17; 127, Figs F33-36.

${ }^{42}$ Cf. the tombstone of Favonius Facilis from Colchester: D'Amato, Sumner 2009: 84, Fig. $72 \mathrm{c}-\mathrm{e}$.

43 Miks 2007: Vortafel C, nos 9 and 10.

44 Bishop, Coulston 2006: 73; Ortisi 2006: 371, Fig. 1; Miks 2007: Fig. 3/A160.

45 Ortisi 2015: 24.

46 Schmidt 1997: 123, P1. 184.

47 Petrie et al. 1886: 45; Thomas s.a.: 13, Fig. 36.

48 Bailey 2008: P1. 50, Figs 3288-3289; Walters 1903: 259, Figs C628-C629; Obmann 2000: 19.

49 Breccia 1934: Pls CXVII/684, CXXL/706.

50 Török 1995: Pl. CLXVII, Fig. 311.

51 Fjeldhagen 1995: 206, Fig. 210. 
The function of terracotta swords and/or scabbards is still unclear. They have been interpreted as toys, ${ }^{52}$ attributes of statues or votive offerings. ${ }^{53}$ The interpretation as a toy can probably be ruled out, since pictorial representations do not provide comparisons, nor were such clay objects found in graves with child burials. In addition, the objects seem too fragile to withstand children playing.

Slight traces of wear on the rings of the terracotta scabbard from Aswan indicate that the object may have been attached to something by means of a string or cord, such as, for example, an altar that served as a house of a divinity or to the wall as a kind of cultic decoration. While the interior of the scabbard did not show any traces, it cannot be excluded that it contained some organic or terracotta object, most probably a sword. Several scabbards and swords from Naukratis were probably made as sets. ${ }^{54}$ The unknown archaeological context of other single scabbard and swords does not give any information as to whether some of these objects formed originally sets.

It is possible that the scabbard from Aswan was used as a part of room or wall decoration in combination with garlands, as is shown on wall paintings from Pompeii or Ephesos, where garlands are often combined with hanging vessels or theatre masks. ${ }^{55}$ The location and composition of different amulets in the tomb from of Seuta(s) in Tuna el-Gebel allows the reconstruction of a garland decorated with amulets which was hanging on the baldachin over the burial-bed. ${ }^{56}$

As mentioned above, the terracotta scabbard and most of the other terracottas from House 32 were found in close proximity to the walls. This makes their use as part of the wall decoration very likely. The coins and the burnt basket fragment found nearby and possibly related to these terracottas may, however, suggest that the whole collection belonged to a house altar that is not preserved. The whole assemblage of terracotta figurines from House 32 is analysed in detail by Martin Fink. ${ }^{57}$

\section{DISCUSSION}

The closest parallels to the detailed decoration of the scabbard from Aswan can be found in the western provinces of the Roman Empire. The terracotta represents a model-like imitation of a contemporary weapon of the Roman Army in use throughout the Empire. Such imitations in clay seem to be an Egyptian speciality (see above). The very detailed transformation of a foreign weapon into a locally produced terracotta is evidence of the strong influence of the Roman army in Aswan, one of the most important garrison towns in Egypt, where the majority of the population was involved with the Roman army in one way or another

\footnotetext{
52 Petrie et al. 1886: 45; Obmann 2000: 19, n. 144.

53 Fjeldhagen 1995: 22; Bailey 2008: 82-83; Abdelwahed 2016: 55.

54 Bailey 2008: P1. 50, Fig. 3288.

55 Lang-Auinger 1998: 129, no. 44.

56 Kessler, Brose 2008: 23; 40.

57 See above, note 7.
} 
as documented by the ostraca and other epigraphical documents. ${ }^{58}$ The same influences are manifested in the case of sword/dagger examples from Naukratis, ${ }^{59}$ albeit less precise to pin down. The objects from Naukratis can be traced back to metal models. ${ }^{60}$ Parallels, especially for the scabbards from Naukratis, can be found on miniature votive offerings, made of metal, from pits in Millau (Condatomagus) and Lyon (Lugdunum) in France. ${ }^{61}$

As the terracotta scabbard from Aswan was beyond any question a model of a part of a weapon, a military connotation of the context seems plausible. Would the object have been dedicated as an ex-votum by a soldier? No evidence from the remains of the building can support this hypothesis. Nevertheless, even if there are only few militaria from Area $13 \mathrm{c}$, such as a horse harness, brooches of Type 'Aucissa' and a buckle probably from armour, they seem to provide sufficient evidence for a military presence in this part of the Roman town. ${ }^{62}$

Considering the presented evidence an interpretation of the object as a gladius scabbard seems most probable. The detailed representation of decorative and technical details of contemporary scabbards is evidence of a well-established knowledge of this weapon. The terracotta shows typical features of both the Pompeianus and Mainz types of gladii. While the frame of the scabbard ('Rahmenscheide') is similar to the Mainz type, the placement of the horizontal and vertical strips (the grid-like decoration, which may have been an imitation of leather or textile strips), the central position of the suspension rings and the stocky ribbed knob are indicators of the Pompeii type.

The detailed execution leads to the assumption that the scabbard was presumably ordered by a member of the Roman army at a local workshop specialising in terracottas. Ostraca found in other parts of Aswan tell us that soldiers stationed in Syene had elements of their military equipment manufactured or repaired locally. ${ }^{63}$

The question, whether the object, which is definitely a miniaturised and slightly compressed imitation of a scabbard, may have served as a votive or as an element of decoration, cannot be answered with the evidence at hand.

It has to be kept in mind that the object was found in a purely domestic setting and may thus be seen as evidence of the high impact of Roman military and cultural influences on the civil society of the town of Syene. The scabbard was above all an easily recognisable marker.

${ }^{58}$ CIL III, 14147.1 = Dessau 8899; Cagnat 1896: 39-41; Sayce 1896: 107-109; Locher 1999: 83-86. For any information concerning ostraca the present author is indebted to Sofia Torallas Tovar, University of Chicago, who studies the ostraca found by the Swiss-Egyptian Joint Mission in Aswan.

59 Bailey 2008: P1. 50, Figs 3288-3293.

60 Obmann 2000: 19.

${ }^{61}$ Kiernan 2009: 79, Fig. 3.22, v, vii.

62 Hepa 2014: 154-156.

63 Pilgrim et al. forthcoming. 


\section{References}

Abdelwahed, Y.E.H. 2016: Houses in Graeco-Roman Egypt. Arenas for ritual activity, Oxford

Bailey, D.M. 2008: Catalogue of the Terracottas in the British Museum IV. Ptolemaic and Roman Terracottas from Egypt, London

Bishop, M.C., Coulston, J.C. 2006: Roman military equipment from the Punic Wars to the fall of Rome, Oxford

Breccia, E. 1934: Terrecotte figurate greche e greco - egizie del Museo di Alessandria, Monuments de l'Égypte gréco-romaine II/2, Bergamo

Cagnat, R. 1896: Quatre inscriptions Latines inédites d'Assouan, CRAIBL 40/1, 37-45

Crummy, P., Moyes, R.H., Bayley, J. 1992: Excavations at Culver Street, the Gilbert School, and other site in Colchester 1971-1985, Colchester

D'Amato, R., Sumner, G. 2009: Arms and Armour of the Imperial Roman Soldier. From Marius to Commodus, 112 BC-AD 192, Yorkshire

Deschler-Erb, E. 1999: Ad arma! Römisches Militär des 1. Jahrhunderts n. Chr. in Augusta Raurica, Forschungen in Augst 28, Augst

Dolenz, H. 1998: Eisenfunde aus der Stadt auf dem Magdalensberg, Archäologische Forschungen zu den Grabungen auf dem Magdalensberg 13, Kärtner Museumsschriften 75, Klagenfurt

Feugère, M. 2002: Applique de fourreau de glaive augustéen de Saintes (F, CharenteMaritime), Instrumentum 15, 12-13

Fischer, T. 2012: Die Armee der Caesaren. Archäologie und Geschichte, Regensburg

Fjeldhagen, M. 1995: Graeco-Roman Terracottas from Egypt, Catalogue, Ny Carlsberg Glyptotek, Copenhagen

Hepa, M. 2012: Ein griechisch-römischer Siedlungsbefund in Assuan/Ägypten. Areal 13c. Stratigraphie und Kleinfunde, unpublished MA thesis, University of Cologne

Hepa, M. 2014: Die römischen Kleinfunde aus Assuan, EtudTrav XXVII, 152-159

Istenič, J. 2003: Augustan sword-scabbards with net-like fitments, ArhVest 54, 271-279

Kessler, D., Brose, P. 2008: Ägyptens letzte Pyramide. Das Grab des Seuta(s) in Tuna el-Gebel, Haar

Kiernan, P. 2009: Miniature Votive Offerings in the north-west Provinces of the Roman Empire, Mentor 4, Mainz-Ruhpolding

Lang-Auinger, C. 1998: Masken aus Ton und Masken in der Wandmalerei - eine Gegenüberstellung, JÖAI 67, 117-131

Locher, J. 1999: Topographie und Geschichte der Region am Ersten Nilkatarakt in griechisch-römischer Zeit, AfP Beiheft 5, Stuttgart-Leipzig

Martin-Kilcher, S., Wininger, J. 2017: Syene III. Untersuchungen zur römischen Keramik und weiteren Funden aus Syene / Assuan (1.-7. Jahrhundert AD), Grabungen 2001-2004, B̈̈BA 20, Gladbeck

Miks, Ch. 2007: Studien zur römischen Schwertbewaffnung in der Kaiserzeit, Kölner Studien zur Archäologie der Römischen Provinzen 8, Köln 
Müller, W. 2014: Syene (Ancient Aswan) in the first Millennium AD, [in:] O'Connell, E.R. (Ed.), Egypt in the First Millennium AD. Perspectives from New Fieldwork, British Museum Publications on Egypt and Sudan 2, Leuven, 59-69

Müller, W., Hepa, M. 2017: Two Baths from Syene, [in:] Redon, B. (Ed.), Collective Baths in Egypt 2. New Discoveries and Perspectives, EtudUrb 10, Le Caire, $51-64$

Obmann, J. 2000: Studien zu römischen Dolchscheiden des 1. Jahrhunderts n. Chr. Archäologische Zeugnisse und bildliche Überlieferungen, KSARP 4, Köln

Ortisi, S. 2006: Gladii aus Pompeji, Herculaneum und Stabia, Germania 84, 369-385

Ortisi, S. 2015: Militärische Ausrüstung und Pferdegeschirr aus den Vesuvstädten, Palilia 29, Wiesbaden

Petrie, W.M.F., Smith, C., Gardner, E., Head, B.V. 1886: Naukratis. Part I: 1884-5, London Pilgrim, C. von 2011: „Auf Elephantine sollten wir überhaupt einmal graben.“ Ein Streifzug durch die Forschungsgeschichte der Städte am Ersten Nilkatarakt, [in:] Morenz, L.D., Höveler-Müller, M., El-Hawary, A. (Eds), Zwischen den Welten: Grabfunde von Ägyptens Südgrenze, Rahden, 63-84

Pilgrim, C. von, Bruhn, K.C., Dijkstra, J.H.F., Wininger, J., el-Asfar, A., el-Saedy, I., ed-Din Mustafa, M., Abdel Atif, U. 2006: The Town of Syene, Report on the $3^{\text {rd }}$ and $4^{\text {th }}$ Season in Aswan, MDAIK 62, 215-277

Pilgrim, C. von, Bruhn, K.C., Kelany, A., el-Asfar, A., Hakim Haddad, A., ed-Din Mustafa, M. 2004: The Town of Syene, Preliminary Report on the $1^{\text {st }}$ and $2^{\text {nd }}$ Season in Aswan, MDAIK 60, 119-148

Pilgrim, C. von, Hepa, M., Nováček, J., Nováček-Scheelen, K., Müller, W., Torallas Tovar, S. forthcoming: Report on the $18^{\text {th }}$ Season of the Joint Swiss-Egyptian Mission in Syene / Old Aswan (2017/2018)

Rembart, L. 2018: Kulturelle Identitäten Oberägyptens in ptolemäisch-römischer Zeit am Beispiel von Syene. Typochronologie, Akkulturation und wirtschaftsarchäologische Interpretation von ausgewählten Fundkomplexen aus der Stadtgrabung, unpublished $\mathrm{PhD}$ thesis, Paris-Lodron-Salzburg

Saliola, M., Casprini, F. 2012: Pugio - gladius brevis est. History and technology of the Roman battle dagger, BAR-IS 2404, Oxford

Sayce, A.H. 1896: Roman Inscriptions at Assuan, PSBA 18, 107-109

Schalles, H.-J., Schreiter, C., Boelicke, U. 1993: Geschichte aus dem Kies: neue Funde aus dem Alten Rhein bei Xanten. Publikationen zur Ausstellung im Regionalmuseum Xanten vom 6. Juni bis 31. Oktober 1993, Xantener Berichte 3, Köln

Schmidt, S. 1997: Katalog der ptolemäischen und kaiserzeitlichen Objekte aus Ägypten im Akademischen Kunstmuseum Bonn, München

Thomas, R. s.a.: Ptolemaic and Roman figurines, models and coffin-fittings in terracotta, [in:] Villing, A., Bergeron, M., Bourogiannis, G., Johnston, A., Leclère, F., Masson, A., Thomas, R., Naukratis: Greeks in Egypt, s.l., 1-20, https://www.britishmuseum.org/ pdf/Thomas_Ptolemaic_figures.pdf (accessed October 4, 2018)

Török, L. 1995: Hellenistic and Roman Terracottas from Egypt IV, Rome 
Ulbert, G. 1969: Gladii aus Pompeji. Vorarbeiten zu einem Corpus römischer Gladii, Germania 47, 97-128

Unz, Ch., Deschler-Erb, E. 1997: Katalog der Militaria aus Vindonissa. Militärische Funde, Pferdegeschirr und Jochteile bis 1976, Veröffentlichungen der Gesellschaft Pro Vindonissa XIV, Brugg

Walters, H.B. 1903: Catalogue of the Terracottas in the Department of Greek and Roman Antiquities, British Museum, London

Webster, G. 1958: The Roman site at Wall, Staffordshire, London 


\section{ÉTUDES et TRAVAUX XXXI / 2018}

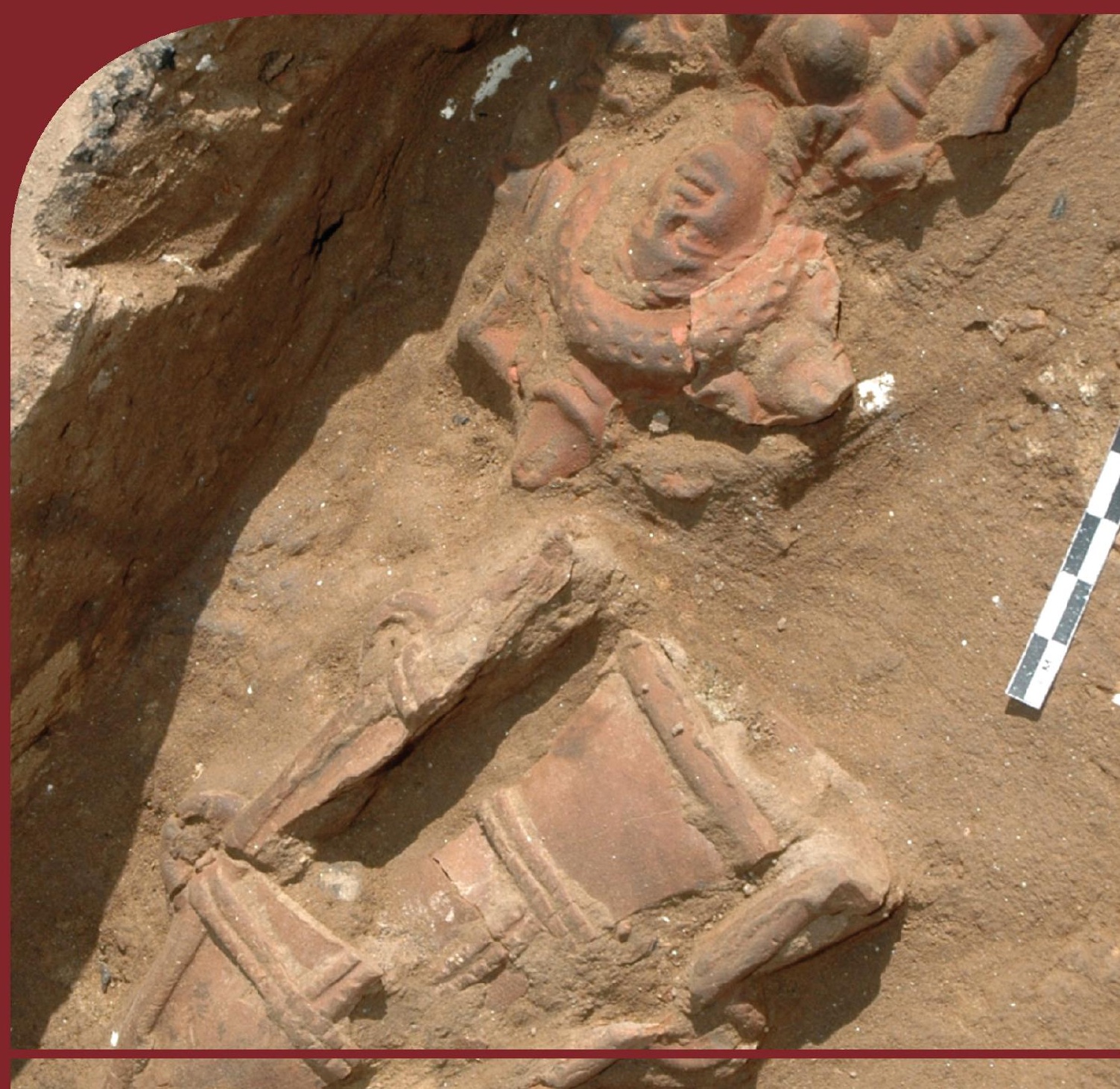

Institut des Cultures iyréditerranéennes et Oilentales FORIKSiO - de PAcadémie Polonaise des Sciences DS PA 


\section{COMITÉ DE RÉDACTION SCIENTIFIQUE}

Maciej Makowski - rédacteur en chef

Jadwiga Iwaszczuk - rédacteur

Mariusz Drzewiecki - sécretaire de la rédaction

Karol Myśliwiec - rédacteur thématique du volume

CONSEIL SCIENTIFIQUE DU JOURNAL

M. Kobusiewicz (IAE PAS, Warszawa), E. Laskowska-Kusztal (IMOC PAS, Warszawa)

D. Michaelides (University of Cyprus, Nicosia)

J.Ch. Moretti (IRAA-MOM, Université de Lyon 2/CNRS)

D. Raue (Ägyptisches Museum der Universität Leipzig), P. Reynolds (ICREA, España)

D. Welsby (British Museum, London)

\section{COMITÉ SCIENTIFIQUE DE LECTURE}

H.D. Baker (University of Toronto), P. Ballet (ArScAn-ESPRI, Université Paris Nanterre),

N. Beaux Grimal (IFAO, Cair/Collège de France, Paris), A. Dodson (University of Bristol),

L. Gabolde (CNRS), C. Gobeil (Egypt Exploration Society, London),

J. Holaubek (Institut für Ägyptologie, Wien), S. Ikram (American University in Cairo),

K. Innemée (Universiteit Leiden), Ch. Leitz (Universität Tübingen),

A. Loprieno-Gnirs (Universität Basel), Ch.E. Loeben (Museen für Kulturgeschichte, Hannover),

S. Ortisi (Universität München), A. Peignard-Giros (HiSoMA-MOM, Université de Lyon 2/CNRS),

E. Rova (Università Ca' Foscari Venezia), A. Sasson (San Diego Natural History Museum),

G. Schreiber (Eötvös Loránd University, Budapest), E. Teeter (University of Chicago),

Y. Tristant (Macquarie University, Sydney), V. Vaelske (independent researcher),

V.W.J. van Gerven Oei (independent researcher), H. Vymazalová (Charles University, Prague),

K. Winther-Jacobsen (Danish Institute at Athens),

J.A. Ostrowski, E. Papuci-Władyka, J. Śliwa (IA JU, Kraków),

R. Czerner (WUST, Wrocław), A. Ćwiek (IA AMU, Poznań),

K. Domżalski (IAE PAS, Warszawa), M. Pinker (FOS UW, Warszawa),

Ł. Niesiołowski-Spanò (IH UW, Warszawa), M. Gawlikowski (PCMA UW, Warszawa), K.O. Kuraszkiewicz (DE FOS UW, Warszawa), M. Barwik, P. Dyczek, W. Godlewski,

S. Rzepka, J. Żelazowski, A. Niwiński (IA UW, Warszawa)

\section{RÉDACTION TECHNIQUE}

Maciej Makowski, Jadwiga Iwaszczuk

CORRECTION LINGUISTIQUE

Jo Harper 
ÉTUDES et TRAVAUX

XXXI 
INSTYTUT KULTUR ŚRÓDZIEMNOMORSKICH I ORIENTALNYCH POLSKIEJ AKADEMII NAUK

\title{
STUDIA i PRACE
}

XXXI

\author{
gO IKŚiO \\ ESA PAN \\ WARSZAWA \\ 2018
}


INSTITUT DES CULTURES MÉDITERRANÉENNES ET ORIENTALES DE L'ACADÉMIE POLONAISE DES SCIENCES

\section{ÉTUDES et TRAVAUX}

XXXI

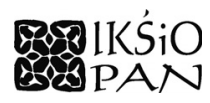

VARSOVIE

2018 
Publication scientifique financée dans le cadre du programme du Ministre de la Science et de l'Éducation Supérieure « Programme National de Développement de l'Humanistique » pour les années 2016-2021 (projet $n^{\circ} 3 \mathrm{bH} 15009983$ )

\title{
Harodowy PROGRAM ROZWOJU HUMANISTYKI
}

\author{
Copyright $($ ) \\ Instytut Kultur Śródziemnomorskich i Orientalnych PAN \\ et les Auteurs \\ Warszawa 2018
}

ISSN 2084-6762

(avant $2011: 0079-3566$ )

e-ISSN 2449-9579

Version première en papier, imprimée en Pologne - 150 copies

Version électronique accessible sur http://www.etudesettravaux.iksiopan.pl

Édition: Polskie Towarzystwo Historyczne et Wydawnictwo Neriton, Warszawa

Conception générale de couverture : J. Iwaszczuk Photo de couverture : P. Moser (C) Schweizerisches Institut für Ägyptische Bauforschung und Altertumskunde in Kairo

(terre cuites d'Aswan/Syene) 


\section{Table des matières}

KAROL MYŚLIWIEC

$(E T=E t u d T r a v / 50) \times 30$

HASSAN Aglan

Hatshepsut and the Apis Race: New Quartzite Relief Fragments

from Dra' Abu el-Naga

Amgad Joseph

Divine Wrath in Ancient Egypt

Amgad Joseph

Pain Infliction, Inflictors and Healers in Egyptian Religious, Magical

and Literary Perceptions

MirosŁaW BarwiK

New Dipinti in the Birth Portico of the Hatshepsut Temple at Deir el-Bahari

KrzyszTOF BorysŁaWsKi, ANNA NiwiŃSKA, ANDRZEJ NiwiŃSKI,

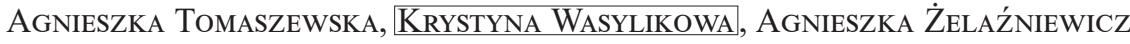

A Bulb of Narcissus on the Egyptian Mummy from University

of Wrocław Collection

LINDA CHAPON

Some Reliefs Representing the King in the Heb Sed Robe Discovered in the Henket-Ankh

Philippe Guillaume

Debunking the Latest Scenario on the Rise of the Pork Taboo

Mariola Hepa

A Clay Gladius Scabbard from Area 13c in the Ancient Roman Town of Syene

Emanuele E. Intagliata

Pinpointing Unrest at Palmyra in Early Islamic Period. The Evidence from Coin Hoards and Written Sources 
KATARZYNA KAPIEC

The Sacred Scents: Examining the Connection Between the ' $n t j w$ and $s f \underline{t}$ in the Context of the Early Eighteenth Dynasty Temples

DOMINIKA MAJCHRZAK

Remarks on the Iconographic Motif of the Birdman in Mesopotamian Glyptic Art of the Third Millennium BC

KAROLINA PAWLIK

Stone Artefacts from Late Roman Occupation Phases in Nea Paphos

ABRÉVIATIONS 
THE VOLUME IS PUBLISHED TO CELEBRATE

THE $50^{\text {TH }}$ ANNIVERSARY

OF THE

ÉTUDES ET TRAVAUX

ESTABLISHED IN 1966 